\author{
KRZYSZTOF SALA \\ Uniwersytet Pedagogiczny w Krakowie, Polska \\ Pedagogical University of Cracow, Poland
}

\title{
Wpływ przemysłu na sytuacię społeczno-gospodarczą i środowisko przyrodnicze gminy Kleszczów
}

\section{Impact of Industry on the Socio-Economic Situation and Natural Environment of the Kleszczów Commune (Poland)}

\begin{abstract}
Streszczenie: Kopalnictwo węgla brunatnego oraz jego wykorzystanie do celów energetycznych wciąż stanowi w Polsce ważne źródło pozyskiwania energii. Tak jak wiele innych sposobów wytwarzania energii niesie za sobą zarówno korzyści, jak i zagrożenia. Celem i przedmiotem publikacji jest przedstawienie sytuacji gospodarczej i ekologicznej gminy Kleszczów w aspekcie funkcjonowania na jej terenie dużych zakładów przemysłowych. Publikacja powstała na podstawie ogólnodostępnej literatury, danych statystycznych i wiadomości netograficznych. W artykule dokonano charakterystyki gminy Kleszczów, korzeni gospodarczych oraz początków wykorzystywania na jej terenie węgla brunatnego. Publikacja prezentuje wpływ istniejącego przemysłu oraz funkcjonowania przedsiębiorstw na sytuację gospodarczą tej najbogatszej gminy w Polsce. Dla zobrazowania poziomu rozwoju gospodarczego ukazano najważniejsze przedsiębiorstwa funkcjonujące w omawianej gminie, przedstawiono poziom dochodów podatkowych per capita oraz miejsce w rankingu przedsiębiorczości. Wpływ gospodarki na sytuację społeczną omawianej gminy ukazano w rankingu zrównoważonego rozwoju. W pracy dokonano charakterystyki wpływu funkcjonującego przemysłu na sytuację gminy. Wskazano na istniejące zagrożenia ekologiczne związane z działającymi zakładami energetycznymi. Dane zostały zilustrowane za pomocą tabel. Metoda badawcza zastosowana w publikacji to analiza danych zastanych oraz krytyka piśmiennicza. Z dostępnej literatury, netografii i danych statystycznych wynika jasno, że przemysł w kluczowy sposób oddziałuje na sytuację gospodarczą i ekologiczną gminy Kleszczów.
\end{abstract}

Abstract: Brown coal mining and its use for energy purposes are still an important source of energy generation in Poland. Like many other ways of generating energy, it brings both benefits and risks. The aim and subject of the publication is to present the economic and ecological situation of the Kleszczów commune in the aspect of the operation of large industrial plants on its territory. The publication was based on publicly available book literature, statistical data, as well as on Internet information. The article describes the Kleszczów commune, economic roots and the beginnings of using lignite in its area. The publication presents the impact of the existing industry and the functioning of enterprises on the economic situation of this richest commune in Poland. To illustrate the level of economic development, the most important enterprises operating in the discussed commune were shown, the level of tax revenue per capita and place in the entrepreneurial ranking were presented. The impact of the economy on the social situation of the commune in question is shown in the ranking of sustainable development. The work characterises the impact of the functioning industry on the situation of the commune. The existing ecological threats related to operating power plants were pointed out. 
The data was illustrated using tables. The research method used in the publication is the analysis of existing data and literary criticism. Based on the available book literature, netography and statistical data, it is clear that the industry has a key impact on the economic and ecological situation of the Kleszczów commune.

Słowa kluczowe: dochody; energetyka węglowa; górnictwo węgla brunatnego; środowisko przyrodnicze; tradycyjne źródła energii

Keywords: coal energy; lignite mining; natural environment; revenues; traditional energy sources

Otrzymano: 6 października 2018

Received: 6 October 2018

Zaakceptowano: 6 lutego 2019

Accepted: 6 February 2019

\section{Sugerowana cytacja/ Suggested citation:}

Sala, K. (2019). Wpływ przemysłu na sytuację społeczno-gospodarczą i środowisko przyrodnicze gminy Kleszczów. Prace Komisji Geografii Przemysłu Polskiego Towarzystwa Geograficznego, 33(1), $143-152$. https://doi.org/10.24917/20801653.331.11

\section{WSTĘP}

Wydobywanie węgla brunatnego w Polsce oraz jego spalanie dla celów energetycznych wciąż stanowi wysoki odsetek sposobów pozyskiwania energii. Produkcja energii w elektrowniach zasilanych węglem brunatnym tylko w 2014 roku wynosiła 54212 GWh, co stanowiło 34,6\% wytworzonej energii elektrycznej w Polsce. Zakłady wydobywające i wykorzystujące węgiel brunatny mają duże znaczenie gospodarcze i społeczne w Polsce, zapewniając m.in. dochody podatkowe czy miejsca pracy. Jednakże należy mieć także na uwadze znaczący wpływ energetyki węglowej na stan środowiska naturalnego.

Celem i przedmiotem publikacji jest przedstawienie sytuacji gospodarczej i ekologicznej gminy Kleszczów w aspekcie funkcjonowania na jej terenie dużych zakładów przemysłowych. W pracy wykorzystano przykład najbogatszej gminy w Polsce - gminy Kleszczów. Publikacja powstała dzięki wykorzystaniu literatury zwartej, danych statystycznych oraz danych netograficznych.

Literatura krajowa dotycząca omawianej problematyki jest bogata. Wpływ przemysłu na rozwój społeczno-gospodarczy i środowisko naturalne znaleźć można w pracach wielu autorów (m.in. Troc, 1974; Jaros, 1975; Pakuła, 1994; Mazur, 2004; Rachwał, 2005; Małachowski, 2007; Zioło, Rachwał, 2015; Zioło, 2017).

Teza postawiona $\mathrm{w}$ pracy to stwierdzenie, że przemysł energetyczny $\mathrm{w}$ istotny sposób determinuje sytuację gospodarczo-społeczną i środowisko przyrodnicze gminy Kleszczów oraz na nie wpływa.

Metodą badawczą wykorzystaną w publikacji jest analiza danych zastanych oraz krytyka piśmiennicza.

Na podstawie zgromadzonych danych źródłowych można wywnioskować z całą pewnością, że przemysł w znaczący sposób wpływa na sytuację gospodarczą i ekologiczną gminy Kleszczów.

\section{ChARAKTERYSTYKA GMinY KLESZCZóW}

Kleszczów to gmina wiejska w województwie łódzkim, w powiecie bełchatowskim. Teren położony jest na pograniczu Wysoczyzny Bełchatowskiej i Kotliny Szczercowskiej. Jego krajobraz charakteryzują równiny, urozmaicone ostańcami morenowymi. Według danych z 30 czerwca 2016 roku gminę zamieszkiwało 5666 osób (GUS, 2018). Na 
terenie gminy znajdują się kopalnia odkrywkowa węgla brunatnego oraz elektrownia Bełchatów (Kaliński, 2009).

Gmina Kleszczów ma bogaty rodowód historyczny. Pierwsze potwierdzone przez archeologów ślady osadnictwa w okolicach Kleszczowa pochodzą z okresu neolitu (Grygiel, 2002). Pierwsze pisane wzmianki o miejscowości zawiera księga Jana Łaskiego z XVI wieku zatytułowana Liber Beneficiorum. Księga wymienia Kleszczów jako jeden z nabytków archidiecezji gnieźnieńskiej (Kusiński, Szczegłów, 2011).

W XIX wieku tereny obecnej gminy stanowiły tygiel narodowościowy. Obok ludności polskiej żyli tu Niemcy, Żydzi oraz potomkowie Braci Czeskich wyznania ewangelickiego. Wspólnota kościoła ewangelickiego funkcjonuje w Kleszczowie do dziś (Podolska, 2010).

Sytuacja gospodarcza gminy uległa wyraźnej zmianie w okresie powojennym (Niżnik, Pączka, 1978). Odkrycie węgla brunatnego w regionie bełchatowskim nastąpiło pod koniec 1960 roku, w czasie poszukiwań gazu ziemnego (Jaros, 1975). Przeprowadzone rok później odwierty potwierdziły występowanie w tym rejonie dużego, zasobnego i korzystnie zalegającego złoża węgla brunatnego. Kilkanaście następnych lat zajęły jego badania i ekspertyzy, w tym czasie trwały również prace projektowe dotyczące przyszłej eksploatacji złoża (Kondracki, 2000).

Praktyczne wykorzystanie odkrytego złoża nastąpiło jednak dopiero w latach siedemdziesiątych, w czasie sprawowania władzy przez Edwarda Gierka (Gajdziński, 2013). Na początku kwietnia 1973 roku powstała delegatura Zjednoczenia Przemysłu Węgla Brunatnego w Bełchatowie jako pierwszy zalążek przyszłego przedsiębiorstwa górniczego. Przełomowy dla kopalni był rok 1975, kiedy to 17 stycznia tego roku zostało utworzone Przedsiębiorstwo Państwowe Kopalnia Węgla Brunatnego Bełchatów w budowie. W tym samym roku rozpoczęło się odwadnianie złoża i montaż pierwszej koparki nadkładowej (Kopalnia Węgla Brunatnego Bełchatów, 2017).

Równocześnie uruchomiono jedną z największych inwestycji lat siedemdziesiątych w Polsce, czyli elektrownię Bełchatów. Funkcjonująca obecnie pod nazwą PGE Górnictwo i Energetyka Konwencjonalna S.A. - Oddział Elektrownia Bełchatów jest największą na świecie elektrownią wytwarzającą energię elektryczną z węgla brunatnego. W Elektrowni Bełchatów eksploatowanych jest obecnie 13 bloków energetycznych o łącznej mocy 5472 MW.

Rosnące potrzeby Elektrowni Bełchatów powodowały wzrost wydobycia węgla brunatnego. Kopalnia osiągnęła docelową zdolność wydobywczą 38,5 mln ton na rok w 1988 roku. Od 1 stycznia 1999 roku Kopalnia Węgla Brunatnego Bełchatów rozpoczęła proces komercjalizacji, stając się spółką akcyjną. Wznowione w 1977 roku prace związane z uruchomieniem Pola Szczerców zintensyfikowano w 1999 roku. Nowa odkrywka ruszyła 21 października 2002 roku. Zasoby całego złoża bełchatowskiego, zgodnie z planem ich zagospodarowania, zostaną wykorzystane do ok. 2038 roku. Współcześnie oba zakłady przemysłowe tworzą ważne ogniwo Piotrkowsko-Bełchatowskiego Okręgu Przemysłowego (Kraina Wycieczek, 2018).

\section{WPŁYW PRZEMYSŁU NA ROZWÓJ GOSPODARCZY GMINY KLESZCZÓW}

Na sytuację gospodarczą omawianej gminy wpływa znacząco umiejscowienie na jej terenie dwóch dużych zakładów przemysłowych (Kopalni Węgla Brunatnego Bełchatów i Elektrowni Bełchatów). Ponadto władze samorządowe zadbały o wzmocnienie 
potencjału gospodarczego gminy Kleszczów poprzez przygotowanie nowych terenów inwestycyjnych. Tereny gminy wchodzą w skład utworzonej w 1997 roku Łódzkiej Specjalnej Strefy Ekonomicznej, która przyciąga nowe przedsiębiorstwa, w tym zwłaszcza kapitał obcy (Grycuk, 2014). Przedsiębiorstwa zlokalizowane są w czterech strefach przemysłowych:

- Strefa przemysłowa nr 1 w Rogowcu - 15 przedsiębiorstw,

- Strefa przemysłowa nr 2 w Kleszczowie - 12 przedsiębiorstw,

- Strefa przemysłowa nr 3 w Żłobnicy - 11 przedsiębiorstw,

- Strefa przemysłowa nr 4 w Bogumiłowie - 15 przedsiębiorstw.

Łącznie na terenie wszystkich czterech stref przemysłowych gminy Kleszczów w sierpniu 2018 roku funkcjonowało ponad 50 przedsiębiorstw. Największe przedsiębiorstwa zlokalizowane na terenie strefy przemysłowej $\mathrm{nr} 2 \mathrm{w}$ Kleszczowie przedstawia tab. 1.

Tab. 1. Najważniejsze przedsiębiorstwa zlokalizowane na terenie strefy przemysłowej nr 2 w Kleszczowie w 2018 roku

\begin{tabular}{|l|l|c|l|}
\hline \multicolumn{1}{|c|}{ Nazwa firmy } & \multicolumn{1}{|c|}{ Kraj pochodzenia } & $\begin{array}{c}\text { Rok rozpoczęcia } \\
\text { działalności na terenie } \\
\text { gminy Kleszczów }\end{array}$ & \multicolumn{1}{|c|}{ Branża } \\
\hline Arix Polska Sp. z o.o. & Włochy & 1999 & $\begin{array}{l}\text { Produkcja środków } \\
\text { czystości }\end{array}$ \\
\hline CFE Polska Sp. z o.o. & Szwajcaria & 2008 & $\begin{array}{l}\text { Produkcja elementów } \\
\text { z polipropylenu }\end{array}$ \\
\hline Colep Polska Sp. z o.o. & Portugalia & 1999 & Produkcja kosmetyków \\
\hline Izolbet Sp. z o.o. & Polska & 2007 & Chemia budowlana \\
\hline Kersten Europe Sp. z o.o. & Holandia & 1997 & $\begin{array}{l}\text { Usługi obróbki profili } \\
\text { stalowych }\end{array}$ \\
\hline Some KSW Sp. z o.o. & Hiszpania & 2007 & $\begin{array}{l}\text { Produkcja wyrobów } \\
\text { metalowych }\end{array}$ \\
\hline Uponor Infra Sp. z o.o. & Finlandia & 2001 & $\begin{array}{l}\text { Produkcja rur z tworzyw } \\
\text { sztucznych }\end{array}$ \\
\hline
\end{tabular}

Źródło: opracowanie własne na podstawie Łódzkiej Specjalnej Strefy Ekonomicznej (2018)

Dane zawarte w tab. 1 wskazują, że na terenie strefy przemysłowej nr 2 w Kleszczowie wśród największych firm dominują firmy produkcyjne o charakterze spółek z ograniczoną odpowiedzialnością. Głównym odbiorcą ich produktów jest branża budowlana. Wśród znaczących podmiotów gospodarczych funkcjonujących w gminie Kleszczów, jednak działających poza wymienionymi strefami przemysłowymi, jest Solpark Kleszczów Sp. z o.o.

Zlokalizowanie na terenie gminy Kleszczów dwóch dużych zakładów energetycznych, a także licznych przedsiębiorstw reprezentujących zróżnicowane branże wpływa pozytywnie na sytuację finansową gminy. Działalność tak wielu przedsiębiorstw na terenie gminy zapewnia wysokie dochody zasilające budżet gminny (Wirtualna Polska, 2018). Kleszczów od lat zajmuje czołową pozycję wśród polskich gmin w zakresie poziomu osiąganych dochodów podatkowych na jednego mieszkańca (tab. 2).

Analiza danych zawartych w tab. 2 pozwala stwierdzić, że dochody podatkowe gminy Kleszczów niemal czterokrotnie przewyższały dochody drugiej w zestawieniu gminy Rząśnia oraz ponad pięciokrotnie pozostałe gminy w zestawieniu. 
Tab. 2. Dochody podatkowe per capita najbogatszych gmin wiejskich w Polsce w 2017 roku oraz ich miejsce w rankingu w latach 2012-2017

\begin{tabular}{|c|c|c|c|c|c|c|c|}
\hline \multirow[t]{2}{*}{ Gmina } & \multirow[t]{2}{*}{ Województwo } & \multicolumn{5}{|c|}{$\begin{array}{l}\text { Miejsce w ogólnopolskim rankingu } \\
\text { zamożności gmin }\end{array}$} & \multirow{2}{*}{$\begin{array}{c}\text { Dochody } \\
\text { podatkowe per } \\
\text { capita w zł }\end{array}$} \\
\hline & & 2012 & 2013 & 2014 & 2015 & 2017 & \\
\hline Kleszczów & łódzkie & 1 & 1 & 1 & 1 & 1 & 31962,75 \\
\hline Rząśnia & łódzkie & 7 & 11 & 4 & 3 & 2 & 8634,17 \\
\hline Kobierzyce & dolnośląskie & 14 & 14 & 12 & 10 & 3 & 5808,52 \\
\hline Mielnik & podlaskie & 10 & 8 & 10 & 12 & 4 & 5793,09 \\
\hline Jerzmanowa & dolnośląskie & 16 & 6 & 6 & 8 & 5 & 5753,53 \\
\hline Rewal & zachodniopomorskie & 2 & 2 & 2 & 2 & 6 & 5741,33 \\
\hline
\end{tabular}

Źródło: opracowanie własne na podstawie Zamożność samorządów 2015 (2018)

Funkcjonowanie firm przemysłowych na terenie gminy przekłada się również na inne wskaźniki gospodarcze. Wybrane wskaźniki gospodarcze i ranking przedsiębiorczości gminy Kleszczów prezentuje tab. 3.

Tab. 3. Wskaźniki i ranking przedsiębiorczości gminy Kleszczów w wybranych latach 2003, 2015, 2016

\begin{tabular}{|l|c|c|c|}
\hline \multicolumn{1}{|c|}{ Wskaźnik } & 2003 & 2015 & 2016 \\
\hline $\begin{array}{l}\text { Wydatki na projekty } \\
\text { inwestycyjne na mieszkańca w zł }\end{array}$ & 1478,96 & 1776,80 & 1081,05 \\
\hline $\begin{array}{l}\text { Odsetek dochodów własnych } \\
\text { w dochodach budżetu }\end{array}$ & 96,57 & 96,82 & 27,04 \\
\hline $\begin{array}{l}\text { Liczba osób pracujących } \\
\text { na 1000 mieszkańców }\end{array}$ & 4579,99 & $-29,14$ & $-23,42$ \\
\hline $\begin{array}{l}\text { Liczba osób bezrobotnych na } \\
1000 \text { mieszkańców }\end{array}$ & $-69,13$ & 74,19 & 73,36 \\
\hline $\begin{array}{l}\text { Liczba podmiotów } \\
\text { gospodarczych } \\
\text { na 1000 mieszkańców }\end{array}$ & 65,99 & 60,00 & 60,00 \\
\hline $\begin{array}{l}\text { Odsetek radnych z wyższym } \\
\text { wykształceniem }\end{array}$ & 33,33 & 1 & 1 \\
\hline Miejsce w rankingu & 1 & 2950 \\
\hline
\end{tabular}

Źródło: opracowanie własne na podstawie Laureaci XIV Konkursu... (2017)

Dane zawarte w tab. 3 pokazują, że gmina Kleszczów wyróżnia się wysokim odsetkiem dochodów własnych w dochodach budżetu, a zwłaszcza dynamicznie malejącym bezrobociem. Omawiana gmina jest również od lat krajowym liderem w zakresie rozwoju przedsiębiorczości.

Kolejny czynnik świadczący o sytuacji gminy Kleszczów stanowi wskaźnik zrównoważonego rozwoju. Wskaźnik zrównoważonego rozwoju określa jakość życia społeczeństwa, oceniając rozwój miast w wymiarze środowiskowym, politycznym, gospodarczym i społecznym (np. transport, stan środowiska naturalnego, wypadki drogowe, warunki życia). Wyniki rankingu zrównoważonego rozwoju jednostek samorządu terytorialnego Politechniki Warszawskiej zaprezentowane zostały w tab. 4. 
Tab. 4. Ranking zrównoważonego rozwoju jednostek samorządu terytorialnego gmin wiejskich w 2015 roku

\begin{tabular}{|c|l|l|l|}
\hline $\begin{array}{c}|c| \\
\text { Miejsce } \\
\text { w rankingu }\end{array}$ & \multicolumn{1}{|c|}{ Powiat } & \multicolumn{1}{|c|}{ Województwo } \\
\hline 1 & Kleszczów & bełchatowski & łódzkie \\
\hline 2 & Kobierzyce & wrocławski & dolnośląskie \\
\hline 3 & Tarnowo Podgórne & poznański & wielkopolskie \\
\hline 4 & Puchaczów & łęczyński & lubelskie \\
\hline 5 & Suchy Las & poznański & wielkopolskie \\
\hline 6 & Baranów & kępiński & wielkopolskie \\
\hline
\end{tabular}

Źródło: opracowanie własne według serwisu samorządowego PAP (2018)

Dane zawarte w tab. 4 wskazują, że według rankingu jednostek samorządu terytorialnego Politechniki Warszawskiej za rok 2015 gmina Kleszczów zajęła pierwsze miejsce w Polsce. Świadczy to o wysokim poziomie jakości życia w omawianej gminie. Na taki stan rzeczy wpływa miejscowa polityka społeczna. Mieszkańcy gminy mogą liczyć m.in. na darmowy basen, wysokie becikowe (5000 zł), dofinansowanie rachunków za prąd, wodę oraz dodatki do wyjazdów kolonijnych dla dzieci.

\section{WPŁYW PRZEMYSŁU NA SYTUACJĘ EKOLOGICZNĄ GMINY KLESZCZÓW}

Oprócz pozytywnych oddziaływań przemysłu na sytuację gminy Kleszczów trzeba również przedstawić ujemne aspekty jego funkcjonowania i oddziaływania na sytuację ekologiczną omawianej jednostki podziału terytorialnego.

W pierwszej kolejności należy zwrócić uwagę na wpływ przemysłu na krajobraz gminy oraz jej bezpośredniego otoczenia. W wyniku lokalizacji na jej terenie zakładów przemysłowych jej krajobraz z naturalnego przekształcił się w wybitnie techniczny, a więc taki, którego elementami dominującymi są budowle techniczne, przemysłowe. Same tylko kominy elektrowni Bełchatów górują nad obszarem na wysokość ok. $300 \mathrm{~m}$ (Giganty mocy, 2018). Do tego należy doliczyć inne elementy techniczne wspomnianej elektrowni (linie przesyłowe, bloki energetyczne).

Bełchatowska kopalnia stanowi największą dziurę w ziemi w Polsce i jedną z największych w Europie, a także na świecie. Ma głębokość 280 m, długość 3,5 km, szerokość 2,5 km. Powierzchnia pola odkrywkowego wynosi 2600 ha. Odpowiada to mniej więcej powierzchni miasta Bełchatów. Odkrywka jest także widoczna z kosmosu. Z punktu widzenia zwykłego obserwatora czy też turysty odkrywka stanowi obszar niemal pustynny, zdegradowany lub noszący znamiona klęski ekologicznej.

Kolejnym elementem negatywnie wpływającym na krajobraz gminy są zwałowiska zewnętrzne Kopalni Węgla Brunatnego Bełchatów. Górujące ponad powierzchnią tej nizinnej gminy hałdy stanowią wątpliwą ozdobę terenu i stwarzają zagrożenia samozapłonu (Gisman, 1949). Wśród nich warto wymienić zlokalizowaną w sąsiedniej gminie Kamieńsk największą hałdę w Polsce o wysokości 386 m. W przypadku Góry Kamieńskiej podjęto jednak szerokie działania rekultywacyjne.

Nie bez wpływu na krajobraz, ale także na stan zdrowia okolicznych mieszkańców, pozostaje funkcjonowanie na terenie gminy składowiska odpadów paleniskowych (popiołów) Bagno-Lubień. Składowisko popiołów zajmuje tereny rolnicze i osiąga wysokość dochodzącą do 20 m. Mieszkańcy gminy Kleszczów skarżą się na uciążliwe pylenie ze składowiska, szczególnie w dni suche i wietrzne. 
Kolejnym elementem godnym opisania jest stan powietrza atmosferycznego na terenie gminy Kleszczów. Głównym źródłem zanieczyszczenia powietrza pozostaje Elektrownia Bełchatów. Oprócz elektrowni źródłami zanieczyszczeń atmosferycznych w gminie są indywidualne ogrzewanie mieszkań i domów oraz komunikacja samochodowa.

Funkcjonująca Elektrownia Bełchatów należy do największych emitentów $\mathrm{CO}_{2}$ do atmosfery w Europie (Gutmann i in., 2014). Tylko w 2013 roku łączna roczna emisja $\mathrm{CO}_{2}$ wyniosła 37,2 mln t, co stanowiło wzrost o 23,5\% w stosunku do roku 2006. W raporcie z 2007 roku Bełchatów został uznany za elektrownię emitującą największe po Elektrowni Turów względne (w przeliczeniu na produkcję energii elektrycznej) ilości gazów cieplarnianych do atmosfery w Polsce - $1090 \mathrm{~kg} \mathrm{CO} / \mathrm{MWh}$. Zestawienie wielkości emisji $\mathrm{CO}_{2}, \mathrm{SO}_{\mathrm{x}}$ oraz $\mathrm{NO}_{\mathrm{x}} \mathrm{w}$ wybranych latach prezentuje tab. 5.

Tab. 5. Emisja $\mathrm{CO}_{2}$, $\mathrm{SO}_{\mathrm{x}}$ oraz $\mathrm{NO}_{\mathrm{x}} \mathrm{w}$ wybranych latach

\begin{tabular}{|l|c|c|c|}
\hline Emisja polutantów/rok & 2013 & 2015 & 2017 \\
\hline $\mathrm{CO}_{2} \mathrm{w}$ mln $\mathrm{t}$ & 37,2 & 37,0 & 37,6 \\
\hline $\mathrm{SO}_{\mathrm{x}} \mathrm{w}$ tys. $\mathrm{t}$ & 61,0 & 75.0 & 60,0 \\
\hline $\mathrm{NO}_{\mathrm{x}} \mathrm{w}$ tys. $\mathrm{t}$ & 40,0 & 34,0 & 28,0 \\
\hline
\end{tabular}

Źródło: opracowanie własne według danych Eurostatu (2018)

Oprócz emisji gazów cieplarnianych omawiana elektrownia jest źródłem zanieczyszczenia metalami ciężkimi. Tylko w 2016 roku Elektrownia Bełchatów wyemitowała do środowiska 2,82 t rtęci. Stanowi to więcej niż emisja całego hiszpańskiego przemysłu (Fakt, 2018). Natomiast w 2017 roku emisja rtęci wzrosła już do 4 t. Wielkość emisji i jej wpływ na zdrowie ludzkie przedstawia tab. 6.

Tab. 6. Najwięksi truciciele wśród europejskich elektrowni w 2016 roku

\begin{tabular}{|l|l|c|c|}
\hline Nazwa elektrowni & Kraj & Przedwczesne zgony/rok & $\begin{array}{l}\text { Wielkość emisji } \mathrm{CO}_{2} \\
\text { w mln ton i miejsce } \\
\text { w rankingu europejskim }\end{array}$ \\
\hline Bełchatów & Polska & 1270 & $34,9 / 1$ \\
\hline Maritsa Est 2 & Bułgaria & 730 & $9,61 / 11$ \\
\hline Kozienice & Polska & 650 & $12,0 / 7$ \\
\hline Drax & Wielka Brytania & 590 & $6,3 / 33$ \\
\hline Rybnik & Polska & 480 & $8,0 / 12$ \\
\hline
\end{tabular}

Źródło: Europe’s Dark Cloud (2018)

Do zagrożeń, jakie powoduje zanieczyszczenie powietrza atmosferycznego, należą m.in.:

- zmiany klimatyczne - wzrost stężeń $\mathrm{CO}_{2}, \mathrm{CH}_{4}, \mathrm{NO}_{2}$ oraz freonów i halonów w górnej warstwie atmosfery poprzez wzmocnienie efektu cieplarnianego prowadzi do częstszych powodzi, susz, huraganów oraz zmiany w tradycyjnych uprawach rolniczych,

- eutrofizacja - nadmiar ilości azotu, pochodzącego z $\mathrm{NO}_{2}$ i $\mathrm{NH}_{3}$ docierającego z powietrza do zbiorników wodnych prowadzi do zmian w ekosystemach, 
- kwaśne deszcze - opady atmosferyczne o odczynie kwaśnym, zawierające kwasy wytworzone w reakcji wody z pochłoniętymi z powietrza gazami, jak: dwutlenek siarki, tlenki azotu, siarkowodór, chlorowodór, wyemitowanymi do atmosfery $\mathrm{w}$ procesach spalania paliw oraz różnego rodzaju produkcji przemysłowej; prowadzą do zmian w ekosystemach oraz bezpośrednio wpływają na życie i zdrowie ludzi (Woś, 2008).

Stosowana w gminie eksploatacja węgla brunatnego metodą odkrywkową niesie ze sobą wiele skutków. Najważniejszym i najbardziej widocznym z nich jest wyłączenie dużych obszarów gminy spod użytkowania rolniczego i leśnego. Niszczona jest pokrywa glebowa w obrębie wyrobiska, zwałowiska zewnętrznego i obiektów pomocniczych.

Jakość gruntów jest głównym czynnikiem ograniczającym możliwości produkcyjne, rozwój i intensyfikację rolnictwa gminy. Stosunki wodne na terenie gminy, podobnie jak i gleby, nie są korzystne dla rolnictwa. Następstwem niewielkich opadów, znacznego parowania terenowego oraz niskiej retencyjności jest pojawiający się często deficyt wody. Ponadto sąsiedztwo kopalni węgla brunatnego oraz elektrowni zlokalizowanych na obszarze gminy Kleszczów wpływa na zniekształcenie sieci wód powierzchniowych (ujęcie w kanały bądź przełożenie rzek, zasypanie koryt), a także na zaburzenie stosunków wodnych (lej depresyjny, kłopoty z odpływem wód na terenach podmokłych). Zmienia się rzeźba terenu - powstają nowe zagłębienia i wzniesienia oraz rowy ziemne, betonowe i korytkowe służące do odprowadzania wody. Często jest to woda zanieczyszczona piaskiem i pyłem.

Wśród innych problemów ekologicznych gminy warto wymienić także:

- konieczność ochrony przed hałasem,

- konieczność ochrony zasobów przyrodniczych,

- konieczność racjonalnego użytkowania zasobów naturalnych,

- konieczność doskonalenia i racjonalizowania systemu gospodarki odpadami,

- konieczność rozwijania współpracy z gminami sąsiednimi na rzecz wspólnej ochrony środowiska,

- zagrożenie poważnymi awariami, w tym ekologicznymi,

- prowadzenie działań zmierzających do pogłębienia świadomości ekologicznej mieszkańców (Bernaciak, Spychała, 2009).

\section{ZAKOŃCZENIE}

Przemysłowy charakter omawianej w publikacji gminy Kleszczów bez wątpienia w pozytywny sposób wpływa na jej sytuację gospodarczą. To dzięki zakładom przemysłowym oraz funkcjonującym przedsiębiorstwom gmina ma pokaźne dochody finansowe oraz jest w stanie sprostać wielu wyzwaniom ekonomiczno-społecznym. Trzeba jednak mieć na uwadze, że działalność przemysłowa w gminie zostanie ograniczona w perspektywie nadchodzących lat. Wydobywanie węgla brunatnego na terenie gminy zakończy się w 2020 roku. Wprawdzie elektrownia będzie działać nadal, ale przychody z podatków znacznie się zmniejszą. Zakończenie eksploatacji węgla w kopalni w Kleszczowie stworzy przed gminą nowe perspektywy związane z rozwojem turystyki i rekreacji. Nieczynne wyrobisko stanie się bowiem najgłębszym sztucznym zbiornikiem wodnym w Polsce. 
Konsekwencją funkcjonowania sektora energetycznego w gminie, choć nie tylko, jest poważny wpływ na środowisko przyrodnicze. Warto wspomnieć o negatywnym wpływie na krajobraz, atmosferę, gleby czy też stosunki wodne. Reasumując, łącząc pozytywne i negatywne elementy funkcjonowania przemysłu na obszarze gminy Kleszczów, otrzymujemy pełny obraz jej warunków rozwoju.

\section{Literatura \\ References}

Bernaciak, A., Spychała, M. (2009). Programowanie ochrony środowiska w gminie, czyli jak skutecznie zaplanować i wdrożyć gminny program ochrony środowiska, t. 1. Poznań: Sorus.

Europe's Dark Cloud (2018, 30 sierpnia). Pozyskano z https://env-health.org/IMG/pdf/dark_cloud-full_report_final.pdf

Eurostat (2018, 14 lipca). Pozyskano z https://ec.europa.eu/eurostat

„Fakt” (2018, 5 lutego). Pozyskano z https://www.fakt.pl/pieniadze/biznes/elektrownia-belchatow-emituje-wiecej-rteci-niz-caly-hiszpanski-przemysl

Gajdziński, P. (2013). Gierek. Człowiek z węgla. Poznań: Wydawnictwo Poznańskie.

Giganty mocy (2018, 10 czerwca). Pozyskano z http://gigantymocy.pl/o-ekspozycji/gigantyczne-ciekawostki

Gisman, S. (1949). Słownik górniczy. Hasło: hałda. Katowice: Instytut Węglowy, 87.

Grycuk, A. (2014, 14 marca). Centra nowoczesnych usług biznesowych w Polsce. Pozyskano z sejm. gov.pl

Grygiel, R. (red.) (2002). Badania archeologiczne na terenie odkrywki Szczerców Kopalni Węgla Brunatnego Bełchatów S.A. Łódź: Fundacja Badań Archeologicznych K. Jażdżewskiego.

GUS (2018, 12 lipca). Pozyskano z http://stat.gov.pl/

Gutmann, K., Huscher, J., Urbaniak, D., White, A., Schaible, Ch., Bricke, M. (2014). Europe's Dirty Thirty. CAN Europe, WWF European Policy Office, HEAL, EEB i Climate Alliance Germany, 10.

Jaros, J. (1975). Zarys dziejów górnictwa węglowego. Warszawa-Kraków: Wydawnictwo Naukowe PWN.

Kaliński, T. (2009). Polska. Nawigator turystyczny. Warszawa: Carta Blanca, wyd. 4.

Kondracki, J. (2000). Geografia regionalna Polski. Warszawa: Wydawnictwo Naukowe PWN.

Kopalnia Węgla Brunatnego Bełchatów (2017, 23 listopada). Pozyskano z https://kwbbelchatow.pgegiek.pl/O-oddziale/Historia-Kopalni

Kraina Wycieczek (2018, 22 września). Pozyskano z https://krainawycieczek.pl/kopalnia-wegla-brunatnego-belchatow

Kusiński, J., Szczegłów, P. (2011). Po drodze. Województwo łódzkie. Łódź: Wydawnictwo Jacek Kusiński.

Laureaci XIV Konkursu Zrównoważonego Rozwoju Jednostek Samorzq̨du Terytorialnego. Edycja 2017 (2017, 15 grudnia). Warszawa: Anagmis. Pozyskano z https://anagmis.files.wordpress.com/2017/11/1_ranking_punktacji_171106.pdf

Łódzka Specjalna Strefa Ekonomiczna (2018, 15 sierpnia). Pozyskano z http://sse.lodz.pl

Małachowski, K. (2007). Gospodarka a środowisko i ekologia. Warszawa: Wydawnictwo Fachowe.

Mazur, E. (2004). Środowisko przyrodnicze: zagrożenie, ochrona i kształtowanie. Szczecin: Wydawnictwo Naukowe Uniwersytetu Szczecińskiego.

Niżnik, A.M., Pączka, S. (1978). Kierunki przemian struktury przestrzennej Bełchatowa. Studia Regionalne 2(7).

Pakuła, L. (1994). Rewitalizacja obszarów przemysłowych Zespołu Miejskiego GOP-u. Rocznik Naukowo-Dydaktyczny WSP w Krakowie, 170. Prace Geograficzne, 15, 131-142.

Podolska, J. (2010). Spacerownik śladami Żydów ziemi łódzkiej. Warszawa: Agora.

Rachwał, T. (2005). Zachowania głównych przedsiębiorstw przemysłowych w strukturze obszaru metropolitalnego. Biuletyn Komitetu Przestrzennego Zagospodarowania Kraju Polskiej Akademii Nauk, 222, 158-169. 
Serwis samorządowy PAP (2018, 30 czerwca). Ranking JST zrównoważonego rozwoju gminy wiejskie cz. I. Pozyskano z http://samorzad.pap.pl/depesze/wiadomosci_centralne/178685/ Ranking-JST-Zrownowazonego-Rozwoju---gminy-wiejskie-cz--I

Troc, M. (1974). Elektrownie przykopalniane w Śląsko-Krakowskim Zespole Okręgów Przemysłowych, ich rola i perspektywy rozwoju. Folia Geographica, Series GeographicaOeconomica, 7.

Wirtualna Polska (2018, 20 czerwca). Pozyskano z https://wiadomosci.wp.pl/w-tej-gminie-chca-mieszkac-polacy-kleszczow-nazywany-jest-polskim-kuwejtem-6160138275088513a

Woś, A. (2008). Klimat Polski. Warszawa: Wydawnictwo Naukowe PWN.

Zamożność samorządów 2015 (2018, 11 września). Pozyskano z http://www.wspolnota.org.pl/ fileadmin/user_upload/Andrzej/Ranking_-_Zamoznosc_samorzadow_2015_r.pdf

Zioło, Z. (2017). Wpływ przemysłu i usług na rozwój społeczno-gospodarczy układów przestrzennych. Prace Komisji Geografii Przemysłu Polskiego Towarzystwa Geograficznego 31(4), $7-24$.

Zioło, Z., Rachwał, T. (red.) (2015). Procesy transformacji przemysłu i usług w regionalnych i krajowych układach przestrzennych. Prace Komisji Geografii Przemysłu Polskiego Towarzystwa Geograficznego, 15.

Krzysztof Sala, dr, adiunkt, Uniwersytet Pedagogiczny im. Komisji Edukacji Narodowej w Krakowie, Instytut Prawa, Administracji i Ekonomii, Katedra Ekonomii i Polityki Gospodarczej. Absolwent międzynarodowych stosunków gospodarczych (specjalność studia europejskie) na Uniwersytecie Ekonomicznym w Krakowie (studia magisterskie) zakończonych dyplomem na podstawie pracy „Realizacja polityki ekorozwoju w krajach skandynawskich", podyplomowych studiów w zakresie zarządzania jakością i ochroną środowiska w Wyższej Szkole Zarządzania i Bankowości w Krakowie oraz Kolegium Zarządzania i Finansów Szkoły Głównej Handlowej w Warszawie, zakończone uzyskaniem tytułu doktora nauk ekonomicznych na podstawie rozprawy „Nowe rodzaje turystyki jako przejaw postmodernizmu zachowań konsumenckich w Polsce”. Wieloletnie doświadczenie $\mathrm{w}$ praktyce gospodarczej na różnych stanowiskach zawodowych, $\mathrm{w}$ tym stanowiskach menedżerskich. Doświadczenie w pracy naukowo-dydaktycznej zdobyte na uczeniach publicznych i prywatnych. Udział jako trener w szkoleniach finansowanych z UE w ramach programu „Kapitał ludzki” z zakresu dotyczącego szeroko rozumianej turystyki i zarządzania. Do głównych obszarów zainteresowań zalicza politykę gospodarczą i turystyczną Polski i Unii Europejskiej, przedsiębiorczość w sektorze małych i średnich firm oraz zarządzanie strategiczne.

Krzysztof Sala, PhD, associate professor, Pedagogical University of Cracow, Faculty of Political Science, Institute of Law, Administration and Economics, Department of Economics and Economic Policy. A graduate of International Economic Relations (specialisation European Studies) at the Cracow University of Economics (MA) with a paper entitled Implementation of the policy of sustainable development in the Nordic countries, postgraduate studies in the field of quality management and environmental protection at School of Management and Banking in Krakow and the College of Management and Finance School of Economics in Warsaw, leading to a doctoral degree in economic sciences for the thesis New types of tourism as a manifestation of postmodern consumer behavior in Poland. He is experienced in business, including managerial positions. He has gained teaching and research experience at both public and private universities. He has participated as a coach in tourism and management courses funded by the EU as part of the Human Capital programme. The main areas of his interest include economic policy and tourism of Poland and European Union, entrepreneurship in small and medium-sized businesses, and strategic management.

\section{ORCID: 0000-0002-7614-9309}

\section{Adres/address:}

Uniwersytet Pedagogiczny w Krakowie

Wydział Humanistyczny

Instytut Prawa, Administracji i Ekonomii

Katedra Ekonomii i Polityki Gospodarczej

ul. Podchorążych 2, 30-084 Kraków, Polska

e-mail: krzysztofsal@onet.pl 